\title{
Fuel Level Monitoring \& Alert System using IoT
}

\section{G. Vasumathi, J. Dhanasekar, V. Priya}

\begin{abstract}
Unlike an existing system for the fuel level monitoring. It differs by monitoring the fuel level and provide the access to monitor the vehicle in any place with the use of (IOT). Automatically updates the information of fuel entering inside the tank .Principle Purpose Of This Device Is To Prevent Fraud In Refueling Station where now and again the amount of fuel showed in the filling machine isn't genuine amount of fuel entering inside the tanks and fuel theft identification using (iot). KEYWORDS: LCD Display, IOT Module, Mobile Application
\end{abstract}

\section{INTRODUCTION}

\section{A. GENERAL DESCRIPTION}

Float based control of the fuel level system using Raspberry $\mathrm{Pi}$ and a IOT alert message would be received if the theft of fuel is occurred. All this process must be executed in fast manner and response must be in immediate action.A conductivity is been placed in the cap of the fuel tank as to get notification when the cap is been opened. The indication is that an alert will be sent automatically to the concern person via mobile application. Principle intention of this framework is to create a most extreme answer for fuel robbery a sign to the worry individual at the hour of refueling, so this motivation behind the gadget is to counteract misrepresentation in petroleum siphons where now and again the amount of fuel showed in the filling machine isn't the genuine amount of fuel going inside the tank[2 ],[4],[6]

\section{B. IOT MODULE}

The IOT (Internet of Things) Drawing addressing the Internet of Things (IOT).The Internet of things (IOT) is the arrangement of physical devices, vehicles ,home machines and various things embedded with equipment, programming, sensors, actuators, and framework organize which enables these articles to interface and exchange data. Everything is uncommonly recognizable through its introduced figuring structure anyway can between work inside the present Internet establishment. [7],[9], [10]

\section{CONTENT}

IOT are generally broad acknowledgment of the developing idea of the structure and administration of the Internet of

Revised Manuscript Received on August 22, 2019.

G.Vasumathi Department of Mechatronics, Bharath Institute of Higher Education \& Research,TamilNAdu Email: vasu.bala06@gmail.com

J.Dhanasekar,, Department of Mechatronics ,Bharath Institute of Higher Education \& Research,TamilNAdu Email: Jdhanasekar81@gmail.com

V.Priya, Department of Mechatronics ,Bharath Institute of Higher Education \& Research,TamilNAdu Email: priyaygna14@gmail.com
Things , reasonable and secure arrangement of IOT arrangements must plan for "anarchic adaptability". Utilization of the idea of anarchic versatility can be reached out to physical frameworks (i.e. controlled true objects), by temperance of those frameworks being intended to represent questionable administration fates . [1],[3],[5]

\section{WORKING}

- The float sensor is used to sense the monitor of the fuel tank and an analog signal is obtained using a voltage divider circuit.

- The Analog signal is given to the Raspberry pi through analog input ports.

- The Raspberry pi Microcontroller reads the input from the sensor and provides the output signal (pulse width modulation signal ) which is given as input to the actuators .

- IOT Module are used as median to notify the alert via mobile application .

- Thus the imitation of fuel theft is received.

\section{A. Estimating the fuel level in the fuel tank}

For estimating the fuel level, a buoy level sensor is utilized. The sensor is utilized to get the level in the fuel tank. The sensor comprises of a potentiometer and a buoy container alongside a pole. The fuel when filled in the tank the level increments,

The transmitting unit with the buoy case which turns as indicated by the development of the pole. The rotational development of the case is moved to the enlistment potentiometer by means of an apparatus component with the goal that the adjustment in the fluid level is changed over into DC sign to a pointer, collector or PC. The case pivots in extent to the adjustment in the fluid level. The rotational speed is expanded or diminished by the rigging system and is moved to the acceptance potentiometer. The potentiometer peruses the worth and pass the contribution to the Analog to Digital converter. The A/D converter gives the 8-piece numeric information as per the fuel level in the tank. For the fuel level estimation PICI8f4550 microcontroller is utilized. Clock 1 is interfaced with the controller so it will empowers the controller to peruse the information in information transport at a specific time interim. At that point read information is put away in the aggregator. The framework comprises of level finder hardware incorporated with IOT module .

After arriving at the basic water level in the tank,an sign is sent through IOT module to the specialist in charge for further activity. 


\section{III. .RASPBERRY PI}

At first glance. That 's the chilly specialized subtle elements ,now for the less unmistakable issues. Alternate machines accessible at the time were the Sinclair Spectrum, BBC Micro,TRS-80(if you lived in the US ) and Apple II. Aside from being moderately reasonable (much of the time) the other thing that these microcomputers shared was straightforwardness ... they booted specifically into a BASIC translator, and you could compose very unpredictable programming totally without anyone else (given a suitable level of ability). Throughout the following 30 years , PCs turned out to be more impervious and complex , and the possibility of programming improvement as something anybody, even a kid, may turn their hands to, turned out to be less and less conceivable.

\section{CAPABILITIES AND LIMITATIONS}

The essential restrictions identified with IOT are the absence of self-ruling activity fueled by setting. The second piece of that announcement is essential .We are obtaining a level of mechanization with IOT-as things get associated , controlling them utilizing programming winds up less demanding . Setting up a couple of tenets/gadgets is alright however as the quantity of gadgets and things around you develops - it will get "restricting " and entangled. The huge restriction IOT needs to defeat throughout the following decade is getting the unique circumstance, and doing activities self-sufficiently. A framework that learns, and adjusts without being arranged.

\section{V.LITERATURE REVIEW}

This paper abridges and audits distinctive innovative improvements for making productive and financially savvy fuel ready framework .Such fuel level observing framework bargains the fuel level drop sign at abruptly with a scope of time and put and whenever caution to the proprietor of the vehicle all the sign will be gotten through the portable application. While equipment development is wonderful, we require UX advancement in equivalent measure to accomplish ease of use in the IOT

\section{VI .CONCLUSION}

The fuel level framework was first made to demonstrate fuel level in quite a while. It was seen that after developments of vehicles and need of exactness was required then the computerized level fuel detecting is executed. Computerized level checking framework indicates exact range however the robbery control couldn't be conceivable thus utilizing the gsm and conductivity this can be controlled. Along these lines, the fuel level robbery and scope of fuel level has been accomplished effectively. Thus, presently it is conceivable that fuel goes into the fuel tank can be checked by the conductivity. The A/D converter with LCD was fitted with the simple fuel check of the bike and the outcome was effectively acquired. The A/D converter demonstrates the measure of fuel in fuel tank in accurate liters ( ex: 1.3,1.4,1.5). The A/D converter demonstrates the definite fuel in liters just when the fuel in the fuel tank in more than 1 liter. The precision level is up to $95-98 \%$ in light of the fact that the mistake was around +or -0.2 liters, in light of the fact that of the fuel in the fuel tank was estimated based on buoy level in the tank and we didn't utilize some other sensors. It shows the accurate liters on the plane streets and shows blunder an incentive on incline surfaces

\section{REFERENCES}

1. Gowri Sankaran, B., Karthik, B. \& Vijayaragavan, S.P. 2019, "Weight ward change region plummeting change for square based image huffman coding", International Journal of Innovative Technology and Exploring Engineering, vol. 8, no. 10, pp. 4313-4316.

2. Gowri Sankaran, B., Karthik, B. \& Vijayaragavan, S.P. 2019, "Image compression utilizing wavelet transform", International Journal of Innovative Technology and Exploring Engineering, vol. 8, no. 10, pp. 4305-4308.

3. Kandavel, N. \& Kumaravel, A. 2019, "Offloading computation for efficient energy in mobile cloud computing", International Journal of Innovative Technology and Exploring Engineering, vol. 8, no. 10, pp. 4317-4320.

4. Vinoth, V.V. \& Kanniga, E. 2019, "Reversible data hiding in encrypting images-an system", International Journal of Engineering and Advanced Technology, vol. 8, no. 6, pp. 3051-3053.

5. Selvapriya, B. \& Raghu, B. 2019, "Pseudocoloring of medical images: A research", International Journal of Engineering and Advanced Technology, vol. 8, no. 6, pp. 3712-3716.

6. Senthil Kumar, K. \& Muthukumaravel, A. 2019, "Bi-objective constraint and hybrid optimizer for the test case prioritization", International Journal of Engineering and Advanced Technology, vol. 8, no. 6, pp. 3436-3448

7. Kavitha, G., Priya, N., Anuradha, C. \& Pothumani, S. 2019, "Read-write, peer-to-peer algorithms for the location-identity split", International Journal of Innovative Technology and Exploring Engineering, vol. 8, no. 9 Special Issue 3, pp. 445-447.

8. Kaliyamurthie, K.P., Michael, G., Anuratha, C. \& Sundaraj, B. 2019, "Certain improvements in alzheimer disease classification using novel fuzzy c means clustering for image segmentation", International Journal of Innovative Technology and Exploring Engineering, vol. 8, no. 9 Special Issue 3, pp. 599-604.

9. Kaliyamurthie, K.P., Sundarraj, B., Geo, A.V.A. \& Michael, G. 2019 "RIB: Analysis of I/O automata", International Journal of Innovative Technology and Exploring Engineering, vol. 8, no. 9 Special Issue 3 , pp. 1019-1022.

10. Velvizhi, R., Rajabhushanam, C. \& Vidhya, S.R.S. 2019, "Opinion mining for travel route recommendation using Social Media Networks (Twitter)", International Journal of Innovative Technology and Exploring Engineering, vol. 8, no. 9 Special Issue 3, pp. 508-512.

11. Kavitha, R., Sangeetha, S. \& Varghese, A.G. 2019, "Human activity patterns in big data for healthcare applications", International Journal of Innovative Technology and Exploring Engineering, vol. 8, no. 9 Special Issue 3, pp. 1101-1103.

12. Pothumani, S., Anandam, A.K., Sharma, N. \& Franklin, S. 2019, "Extended VEOT framework - Implemented in a smart boutique", International Journal of Innovative Technology and Exploring Engineering, vol. 8, no. 9 Special Issue 3, pp. 762-767.

13. Kaliyamurthie, K.P., Michael, G., Krishnan, R.M.V. \& Sundarraj, B. 2019, "Pseudorandom techniques for the internet", International Journal of Innovative Technology and Exploring Engineering, vol. 8, no. 9 Special Issue 3, pp. 915-918.

14. Aravindasamy, R., Jeffrin Rajan, M., Rama, A. \& Kavitha, P. 2019 "Deep learning provisions in the matlab: Focus on CNN facility", International Journal of Innovative Technology and Exploring Engineering, vol. 8, no. 9 Special Issue 3, pp. 990-994.

15. Theivasigamani, S., Linda, M. \& Amudha, S. 2019, "Object sensing and its identification \& motion sensing", International Journal of Innovative Technology and Exploring Engineering, vol. 8, no. 9 Special Issue 3, pp. 545-549.

16. Mary Linda, I., Vimala, D. \& Shanmuga Priya, K. 2019, "A methodology for the emulation of IPv4", International Journal of Innovative Technology and Exploring Engineering, vol. 8, no. 9 Special Issue 3, pp. 848-852.

17. Velvizhi, R., Priya, D.J., Vimala, D. \& Linda, I.M. 2019, "Increased routing algorithm for mobile adhoc networks", International Journal of Innovative Technology and Exploring Engineering, vol. 8, no. 9 Special Issue 3, pp. 1606-1608.

18. Sangeetha, S., Anuradha, C. \& Priya, N. 2019, "DNS in real

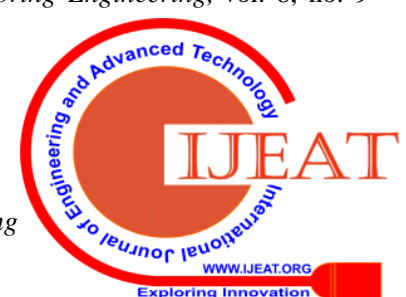


world", International Journal of Innovative Technology and Exploring Engineering, vol. 8, no. 9 Special Issue 3, pp. 937-940.

19. Geetha, C., Vimala, D. \& Priya, K.S. 2019, "Constructing multi-processors and spreadsheets with SKIVE", International Journal of Innovative Technology and Exploring Engineering, vol. 8, no. 9 Special Issue 3, pp. 516-519.

20. Yugendhar, K., Sugumar, V. \& Kavitha, P. 2019, "A novel method of univac using fuzzy logic", International Journal of Innovative Technology and Exploring Engineering, vol. 8, no. 9 Special Issue 3, pp. 435-437.

21. Kaliyamurthie, K.P., Michael, G., Elankavi, R. \& Jijo, S.A. 2019, "Implementing aggregate-key for sharing data in cloud environment using cryptographic encryption", International Journal of Innovative Technology and Exploring Engineering, vol. 8, no. 9 Special Issue 3, pp. 957-959.

22. Jeffrin Rajan, M., Aravindasamy, R., Kavitha, P. \& Rama, A. 2019, "A novel method of object orientation variation in $\mathrm{C}++$ and java", International Journal of Innovative Technology and Exploring Engineering, vol. 8, no. 9 Special Issue 3, pp. 708-710.

23. Nayak, R., Dinesh, S. \& Thirunavukkarasu, S. 2019, "A novel method improvement of rapid miner for the data mining applications", International Journal of Innovative Technology and Exploring Engineering, vol. 8, no. 9 Special Issue 3, pp. 457-460.

24. Sivaraman, K., Krishnan, R.M.V., Sundarraj, B. \& Sri Gowthem, S. 2019, "Network failure detection and diagnosis by analyzing syslog and SNS data: Applying big data analysis to network operations", International Journal of Innovative Technology and Exploring Engineering, vol. 8, no. 9 Special Issue 3, pp. 883-887.

25. Vimala, D., Linda, I.M. \& Priya, K.S. 2019, "Decoupling online algorithms from erasure coding in DNS", International Journal of Innovative Technology and Exploring Engineering, vol. 8, no. 9 Special Issue 3, pp. 950-953.

26. Rama, A., Kumaravel, A. \& Nalini, C. 2019, "Preprocessing medical images for classification using deep learning techniques", International Journal of Innovative Technology and Exploring Engineering, vol. 8, no. 9 Special Issue 3, pp. 711-716.

27. Sangeetha, S., Srividhya, S.R., Anita Davamani, K. \& Amudha, S. 2019, "A procedure for avoid overrun error in universal synchronous asynchronous receiver transmitter (usart) by utilizing dummy join and interrupt latency method", International Journal of Innovative Technology and Exploring Engineering, vol. 8, no. 9 Special Issue 3, pp. 657-660.

28. Aravindasamy, R., Jeyapriya, D., Sundarajan, B. \& Sangeetha, S. 2019, "Data duplication in cloud for optimal performance and security", International Journal of Innovative Technology and Exploring Engineering, vol. 8, no. 9 Special Issue 3, pp. 1156-1158.

29. Aravindasamy, R., Jeffrin Rajan, M., Sugumar, V. \& Kavitha, P. 2019 "A novel method on developing superblocks and the transistor using apodryal", International Journal of Innovative Technology and Exploring Engineering, vol. 8, no. 9 Special Issue 3, pp. 982-985.

30. Sasikumar, C.S. \& Kumaravel, A. 2019, "E-learning attributes selection through rough set theory and data mining", International Journal of Innovative Technology and Exploring Engineering, vol. 8, no. 10 , pp. $3920-3924$.

\section{AUTHORS PROFILE}

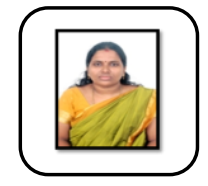

Vasumathi. Assistant, Professor,Department of Mechatronics Bharath Institute of Higher Education \& Research,TamilNAdu

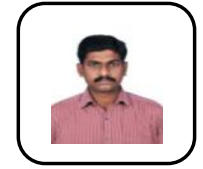

Dhanasekar. J, Assistant Professor,Department of Mechatronics Bharath Institute of Higher Education \& Research,TamilNAdu

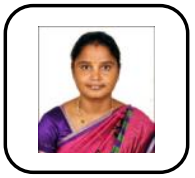

Priya V Assistant Professor,Department of Mechatronics Bharath Institute of Higher Education \& Research,TamilNAdu 